\title{
Natural hybridization between cultivated poplars and their wild relatives: evidence and consequences for native poplar populations
}

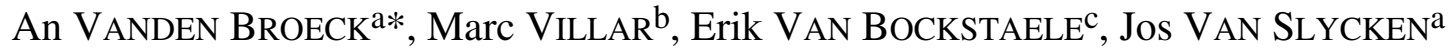 \\ ${ }^{a}$ Institute for Forestry and Game Management (IBW), Research Station of the Flemish Community, Gaverstraat 4, Geraardsbergen, 9500, Belgium \\ b INRA, Unite Amélioration, Génétique et Physiologie Forestières BP 20619, Ardon, 45166 Olivet Cedex, France \\ ${ }^{c}$ Department for Plant Genetics and Breeding, Agricultural Research Centre, Caritasstraat 212, 9090 Melle, Belgium / Department of Plant Production, \\ Ghent University, Coupure Links 653, 9000 Gent, Belgium
}

(Received 15 June 2004; accepted 21 March 2005)

\begin{abstract}
It is recognized that introgressive hybridization and gene flow from domesticated species into their wild relatives can have a profound effect on the persistence and evolution of wild populations. Here, we review published literature and recent data concerning introgressive hybridization involving numerous species of the genus Populus. First, we briefly refer to some concepts and terminology before reviewing examples of natural and anthropogenic hybridization. Second, we examine whether natural genetic barriers could limit introgressive hybridization. Threat and possible consequences of anthropogenic hybridization are discussed in order to finally suggest conservation strategies for native poplar populations.
\end{abstract}

review / Populus / introgression / hybridization / conservation

Résumé - Hybridations entre peupliers cultivés et sauvages : exemples et conséquences pour les populations naturelles. L'introgression et le flux de gènes d'espèces domestiquées vers les espèces sauvages peuvent avoir un rôle déterminant sur la dynamique des populations naturelles. Les objectifs de cette revue sont de faire le point de cette problématique chez les peupliers, à partir de données bibliographiques et de données récentes sur l'introgression et l'hybridation chez les espèces du genre Populus. Dans un premier temps, nous préciserons concepts et terminologie avant de présenter des exemples d'hybridations naturelles ou d'origine anthropogénique entre espèces autochtones et introduites. Nous décrirons ensuite les barrières reproductives qui peuvent limiter les flux de gènes entre espèces. Enfin, nous discuterons des possibles conséquences de l'hybridation et suggèrerons des stratégies de conservation pour les populations naturelles menacées.

article de synthèse / Populus / introgression / hybridation / conservation

\section{INTRODUCTION}

The issues of natural hybridization and introgression (cf. Glossary) between cultivated plants and their wild relatives have been extensively studied in agricultural systems. However, introgression is of particular concern for forest trees because they can have large effects on ecosystem processes and biological diversity [26]. The genus Populus L. (poplars, Salicaceae) is considered as a model forest tree in plant biology [16, 93]. A large collaborative research community is dedicated to its study and this has resulted in a wealth of information on poplar biology and ecology, linking physiology, quantitative genetics (cf. Glossary) and genomics [16, 93]. In particular, Populus nigra L. (European black poplar) has been considered as a model tree in the study of gene resource conservation of wild relatives of cultivated plants $[45,55]$. Much theoretical work on conservation of $P$. nigra has been done in Europe at national and international scales (EU-funded research project EUROPOP, cf. Glossary) [95] and a combined conservation strategy is applied at the European scale, supported by the Populus nigra EUFORGEN (cf. Glossary) network [55]. Despite the many excellent studies of recent years, many questions about hybridization in Populus remain unresolved. It is assumed that the presence of poplar artificial plantations pose a severe potential threat for the diversity and the regeneration of native indigenous poplars. For example, in Europe, the European black poplar is threaten by euramerican ( $P . \times$ canadensis Moench.) and interamerican $(P . \times$ generosa Henry) hybrid poplar and P. nigra varieties such as the male Lombardy poplar (Populus nigra cv. 'Italica' Duroi) [3, 17, 45, 55]. Similarly, in North America, there is potential for extensive gene flow from plantations of cultivated hybrids between $P$. trichocarpa T. \& G. and $P$. deltoides Marshall to native $P$. trichocarpa populations in the Pacific Northwest [25, 94]. Also, as hybrid poplar plantations may soon include genetically engineered trees, a major concern is that genetic resources of wild relatives will be altered through transfer of the transgene by hybridization [25, 31]. Moreover, the observed habitat fragmentation of some native poplar species due to human activities like agriculture and urbanisation of floodplain areas, increases the opportunities for

\footnotetext{
* Corresponding author: An.vandenbroeck@inbo.be
} 
contact with cultivated poplar plantations. This increasing contact provides greater opportunities for the production of hybrid seeds, which is produced at the expense of conspecific (cf. Glossary) seed [57]. Habitat reduction followed by hybridization can lead to the extinction of a rare plant species [32], (for a review see $[57,75]$ ). As a consequence, some authors consider native poplars as the most threatened forest tree species of old natural floodplain forests in the temperate zones [55].

In sum, poplar offers valuable opportunities to address the natural and anthropic effects of hybridization because of its wide spread distribution in the Northern Hemisphere and the numerous cultivars that have been intentionally introduced.

The aim of this review is to examine whether isolation mechanisms (pre and post zygotic) are able to limit hybridization in poplars, the extent and differences between natural and anthropogenic hybridization, and if current approaches to evaluate the threat of hybridization are adequate or not. We discuss if cultivated poplars pose a risk for the conservation of native poplar populations with particular reference to the European black poplar.

\section{CONCEPTS AND TERMINOLOGY}

The process of introgression occurs in many steps that involve several hybrid generations $\left(\mathrm{F}_{1}, \mathrm{~F}_{2}, \mathrm{BC}_{1}, \mathrm{BC}_{2}\right.$ and so on $)$ (cf. Glossary). Thus, hybridization could lead to introgression if the cultivated $\mathrm{F}_{1}$-hybrids backcross (cf. Glossary) to native parental species. Concerning Populus, it is unlikely that natural poplar hybrids are the result of frequent repeated backcrosses due to the recent expansion of poplar cultivation world-wide. In Europe, the intensive poplar cultivation started during the 1940s-1960s [23, 37] and natural hybrids are therefore assumed to represent first generation-hybrids. Therefore we prefer to use the term 'hybridization' rather than 'introgression'.

The threat of a numerically superior species to rare crosscompatible congeners most often springs from human activities [57]. It is therefore important to differentiate between hybridization among native species in the absence of human activities, and 'exotic' events brought about by human disturbances and introductions (i.e. anthropogenic hybridization, cf. Glossary) [2]. For example, major human disturbances have enabled the European white poplar (Populus alba L.), native to Southern Europe, to initiate naturally occurring hybrids on three continents: the grey poplar $(P . \times$ canescens $=P$. alba $\times P$. tremula $)$ in Europe, Rouleau's poplar $(P . \times$ roulwauiana $=P$. alba $\times$ $P$. grandidentata) in eastern North America, and the Chinese white poplar $(P . \times$ tomentosa $=P$. alba $\times P$. adenopoda $)$ in China [62]. In each area, the European white poplar hybridized with a native aspen. In North America, North Europe and China, the European white poplar itself was not native, but was introduced as an ornamental tree and is extremely vigorous.

\section{HISTORICAL CONTEXT OF POPLAR CULTIVATION}

The genus Populus is tremendously varied with 22 to about 85 species (depending on the interpretation of a 'species') distributed throughout the Northern Hemisphere, in both the tem- perate and subtropical zones [30, 35]. Intercrossability among species is one of the foundations of breeding work in the genus Populus (e.g. [30, 86, 111]). Crossing programmes have revealed both the wide extent of potential intercrossability and the very real limitations on it [86, 111]. A list of natural and artificial poplar hybrids is presented in Table I. The impressive sylvicultural qualities of the cultivated hybrids (fast growth, good form and easiness of vegetative propagation) have led to widespread production of cultivated poplar plantations mainly in Europe, North-America and China. The use of hybrid poplars expanded from application in windbreaks to producing wood, fibre and fuel products. In Europe, poplar species frequently used in breeding programmes in order to produce hybrids are the European black poplar (Populus nigra L.) and the North American cottonwoods $P$. deltoides and $P$. trichocarpa. The unit of cultivation and breeding in poplars is a clone, and individual cultivars are normally represented by a single clone [73]. Poplar plantations usually represent one single cultivar or clone in order to minimise the variability in growth and wood quality within the plantation. They represent a very narrow genetic base spread on a very wide scale and may contribute to a large extent to pollen and seed pools. So, the main risk here relates to massive dissemination of few narrow base cultivars [53]. Anthropogenic hybridization between cultivated poplars and their wild relatives may therefore result in genetic swamping of the wild populations. Populus $\times$ canadensis Moench (syn. $P . \times$ euramericana Dode Guinier; cross between $P$. deltoides and $P$. nigra) first arose spontaneously in Europe after the introduction of $P$. deltoides in the 17th Century [112]. After 1960's cultivars of mainly $P . \times$ canadensis and $P . \times$ interamericana (cross between $P$. deltoides and $P$. trichocarpa) have been widespread at alluvial sites across Europe. In some case they replaced the autochthonous black poplar resources [23].

Not all cultivated poplars are hybrids. The Lombardy poplar (Populus nigra cv. 'Italica') is a fastigiated male 'pure' black poplar cultivar that likely originates from central Asia, particularly the Black see region [111]. It probably originated as a spontaneous mutant of Populus nigra [111]. The Lombardy poplar was spread by cuttings throughout Europe (Fig. 1) in the mid-eighteenth century from Italy, where it was found growing on the banks of the Po River in Lombardy [110]. During the 19th century, it was also introduced and widespread in North America, mainly for landscape gardening purposes [110]. $P$. nigra cv. 'Thevestina' is a female black poplar cultivar that also originates from the Black sea region (Central-Asia). This cultivar has been used as ornamental tree for the last centuries in Eastern-European countries, especially in East-Hungary [14]. Besides P. nigra cv. 'Italica' and cv. 'Thevestina', Zsuffa described 20 other $P$. nigra cultivars, most of them used on a local scale [111].

\section{DISPERSAL AND ESTABLISHMENT}

Populus species are predominantly dioecious and thus obligatory outcrossers (cf. Glossary). Both sexes flower in early spring prior to leaf initiation [15]. At maturity, the fruit capsules split and release seeds embedded in significant quantities of pappus (i.e. long white, silky hairs attached to the seed). In addition to being wind-pollinated and obligatory outcrossing, the 
Table I. Some natural and artificial hybrids among species in the genus Populus. All hybrids except the ones indicated as artificial hybrids originating from controlled crosses, have spontaneously formed in areas where the natural range of species overlap or where exotic taxa have been planted near naturally growing poplar trees.

\begin{tabular}{|c|c|c|c|}
\hline Hybrid parents & Hybrid designation & Notes & Ref \\
\hline P. alba L. $\times$ P. adenopoda Maxim. & P. $\times$ tomentosa Carr. & May also be a tri-hybrid containing genes from $P$. tremula & {$[24]$} \\
\hline P. alba L. $\times$ P. grandidentata Mich. & $P . \times$ rouleauiana Boivin & & {$[24]$} \\
\hline P. alba L. $\times$ P. tremuloides Mich. & P. $\times$ heimburgeri Boivin & & {$[24]$} \\
\hline P. alba L. $\times$ P. trumula $\mathrm{L}$. & P. $\times$ canescens $\mathrm{Sm}$ & Gray poplar & {$[24]$} \\
\hline$P$. angustifolia James $\times P$. balsamifera $\mathrm{L}$. & P. $\times$ brayshawii Boivin & Brayshaw's poplar & {$[24]$} \\
\hline $\begin{array}{l}\text { P. angustifolia James } \times \text { P. balsamifera L. } \times \\
\text { P. deltoides Marsh. }\end{array}$ & None & Trihybrid & {$[24]$} \\
\hline$P$. angustifolia James $\times P$. deltoides Marsh. & P. $\times$ acuminata $\mathrm{Rydb}$. & Lanceleaf cottonwood; syn. $P . \times$ andrewsii Sarg. & {$[24]$} \\
\hline$P$. angustifolia James $\times P$. fremontii $\mathrm{S}$. Watts. & P. $\times$ hinckleyana Corr. & & {$[24]$} \\
\hline$P$. angustifolia James $\times P$. nigra L.* & $?$ & & {$[24]$} \\
\hline P. angustifolia James $\times P$. trichocarpa Torr. \& Gray.* & $?$ & & {$[24]$} \\
\hline P. balsamifera L. $\times$ P. deltoides Marsh. & P. $\times$ jackii Sarg. & $\begin{array}{l}\text { Jack's hybrid poplar or heartleaf balsam poplar; also } \\
\text { known as } P \text {. balsamifera var. subcordata or } P \text {. candicans }\end{array}$ & {$[24]$} \\
\hline P. deltoides Marsh. $\times$ P. nigra $\mathrm{L}$. & $\begin{array}{l}\text { P. } \times \text { canadensis } \\
\text { Moench. }\end{array}$ & Euramerican poplar; syn. $P . \times$ euramericana Guin. & {$[24]$} \\
\hline P. deltoides $\times P$. maximowiczii ${ }^{* *}$ & $?$ & Artificial hybrid; Eridano is a clone of this hybrid & {$[34]$} \\
\hline P. deltoides $\times$ P. yunnanensis $* *$ & $?$ & Artificial hybrid; Kawa is a clone of this hybrid & {$[34]$} \\
\hline P. fremontii S. Wats. $\times$ P. deltoides Marsh. & $?$ & & {$[24]$} \\
\hline P. fremontii S. Wats. $\times$ P. nigra $\mathrm{L}$. & P. $\times$ inopina Ecken. & & {$[24]$} \\
\hline P. grandidentata Mich. $\times$ P. tremuloides Mich. & P. $\times$ smithii Boivin & Syn. $P . \times$ barnessi Wag. & {$[24]$} \\
\hline P. heterophylla L. $\times$ P. deltoides Marsh.* & $?$ & Extremely rare and local in areas of the southeastern US & {$[30]$} \\
\hline P. laurifolia Ledeb. $\times$ P. nigra $\mathrm{L}$. & P. $\times$ berolinensis Dippel & $\begin{array}{l}\text { Berlin or Russian poplar; syn. } P . \times \text { rasumowskyana } \\
\text { Schneid. or } P \text {. petrowskyana Schneid. }\end{array}$ & {$[24]$} \\
\hline P. maximowiczii $\times$ P. berolinensis $* *$ & $?$ & Artificial hybrid; Geneva, Oxford are clones of this hybrid & {$[34]$} \\
\hline P. nigra $\times P$. maximowiczii** & $?$ & $\begin{array}{c}\text { Artificial hybrid; Rochester, Maxein, Maxzwo, Maxvier, } \\
\text { Maxfünf are clones of this hybrid }\end{array}$ & {$[34]$} \\
\hline P. tremula L. $\times$ P. tremuloides Mich. & P. $\times$ wettssteinii & Often a triploid & {$[24]$} \\
\hline P. trichocarpa Torr. \& Gray. $\times$ P. fremontii S. Wats. & P. $\times$ parryi Sarg. & Parry cottonwood & {$[24]$} \\
\hline P. trichocarpa Torr. \& Gray. $\times$ P. deltoides Marsh. & P. $\times$ generosa Henry & Interamerican poplar; syn. $P . \times$ interamericana Brockh. & {$[24]$} \\
\hline$(P$. deltoides Marsh $\times P$. nigra L. $) \times P$. balsamifera $\mathrm{L}$. & $P . \times$ rollandii & Trihybrid; very similar to $P . \times$ jackii & {$[24]$} \\
\hline $\begin{array}{l}(P . \text { deltoides } \text { Marsh. } \times \text { P. nigra } \mathrm{L} .) \times P \text {. yunanensis } \\
\text { Dode }\end{array}$ & $?$ & & {$[24]$} \\
\hline$(P$. laurifolia Ledeb. $\times P$. nigra $\mathrm{L}) \times$.$P . balsamifera \mathrm{L}$. & None & Trihybrid & {$[24]$} \\
\hline$(P$. laurifolia Ledeb. $\times$ P. nigra L. $) \times$ P. deltoides March. & None & Trihybrid & {$[24]$} \\
\hline
\end{tabular}

pappus of the seeds promotes wind dispersal over great distances resulting in high rates of migration and high gene flow (cf. Glossary) and genetic diversity [39, 56]. Poplars are prolific seed producers. Old trees can produce over 50 million of seeds in a single season [62]. Seedlings colonise moist, recently exposed soil (due to previous flooding in winter) along gravel bars, sandbars and riverbanks within riparian corridor. Poplar seeds are small and rapidly lose viability [15]. Continuous moisture is required for seed germination. If river levels decline too rapidly, seedlings succumb to drought stress. Seedlings that establish on moist soils at lower river levels are subject to later removal or damage by the scouring of floodwaters [15]. Collectively, these environmental constraints contribute to the infrequent establishment of seedlings, on the order of every 10 to 20 years depending on climatic conditions and channel morphology [15]. The age of reproductive maturity varies among native species from five to ten years, yet in some natural populations may not occur until the trees are 15 to 20 years [15, 85], limiting introgression events. In contrast, hybrid poplars grown in well-maintained plantations commonly attain reproductive maturity in four years [94].

Poplar species are also capable of asexual or vegetative reproduction, as an alternative to regeneration from seed. Asexual reproduction is promoted only by flood disturbances when through extended periods of submergence and/or mechanical damage to parent plants, dormant primordia (cf. Glossary) in 


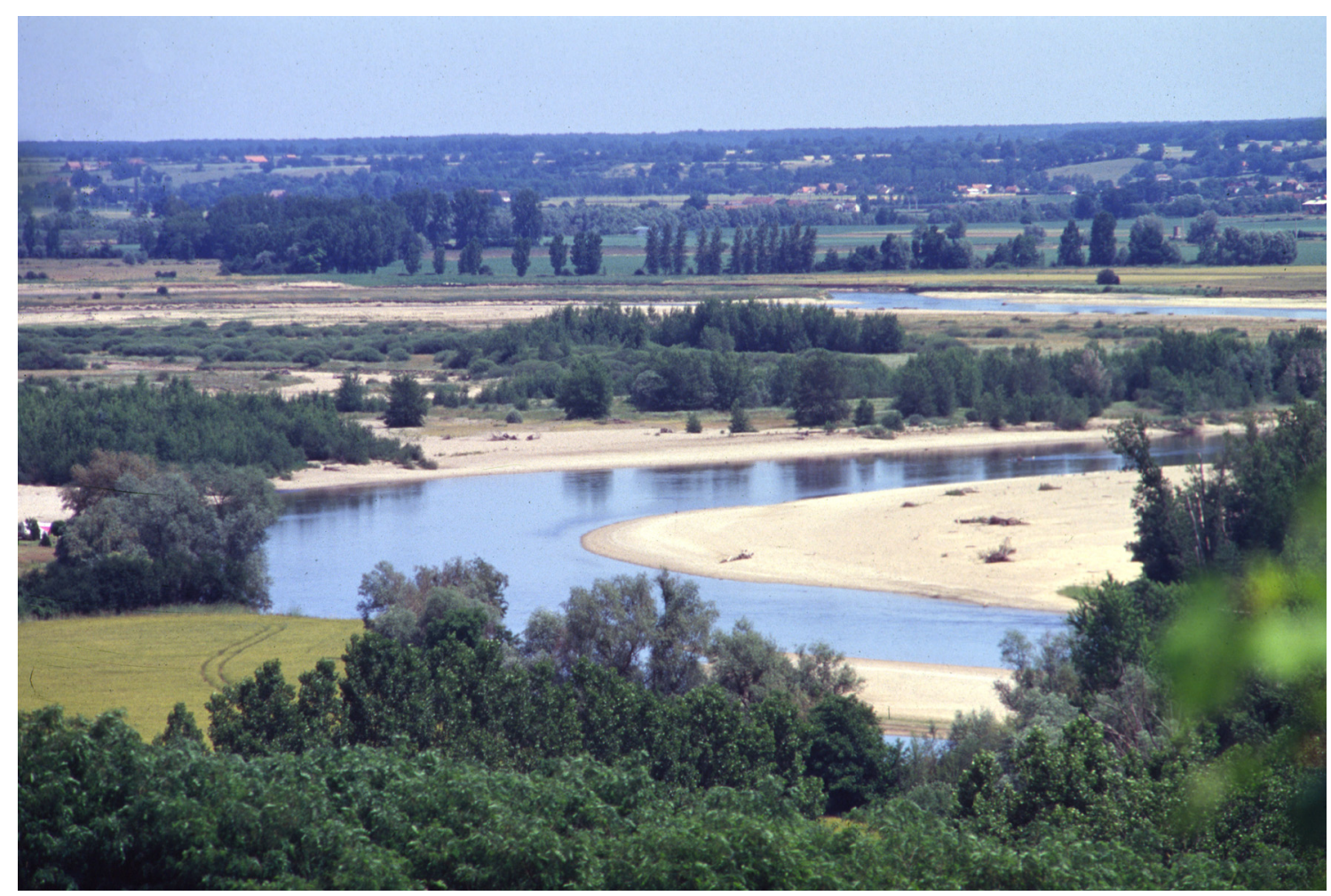

Figure 1. Natural reserve of Val d'Allier (Allier, France). Presence of wild Populus nigra populations and the ornamental male Populus nigra cv. 'Italica' (in the background).

roots and shoots are stimulated to produce new shoots and roots $[8,9]$. Thus, genotypes can persist on sites for long time periods beyond the longevity of single trees [89]. There is also evidence of cladoptosis (cf. Glossary), in which short shoots abscise and can be carried long distances on watercourses and subsequently take root [38].

\section{REPRODUCTIVE ISOLATION MECHANISMS}

Several authors have reported on mechanisms that limit (in whole or in part) gene flow between the hybrids and the parental species. Reproductive isolating mechanisms are generally divided into two categories based on whether they act before or after fertilization (Fig. 2). Mechanisms that act to prevent mating are referred to as prezygotic, whereas those that act to reduce the viability or fertility of the hybrid zygote or later-generation hybrid offspring are referred to as postzygotic [77].

\subsection{Prezygotic barriers}

Pollen competition (Figs. 3 and 4) seems to be an important process in limiting the production of hybrid progeny in Populus. Rajora [63] observed competition among pollen of $P$. deltoides, $P$. nigra and $P$. maximowiczii A. Henry in fertilizing $P$. deltoides ovules. The low frequencies of interspecific matings relative to conspecific matings in pollen-mix controlled crosses suggest conspecific pollen advantage $[63,99]$. As a result, the relative fertilisation success of a pollen species depends upon the species constitution of the pollen mix. Similar results were obtained by Benetka et al. [11] and Vanden Broeck et al. [99] with crossing experiments of $P$. nigra females: when. $P . \times$ canadensis pollen was used in mixtures with $P$. nigra pollen, most of the seedlings were fathered by $P$. nigra. Pollen competition was also studied in detail for Louisiana irises (Iris fulva and Iris hexagona). These studies have focussed on conspecific pollen advantage, including measurements of pollen tube lengths in conspecific and heterospecific styles and examination of hybrid seed production following different types of controlled pollinations (for a review see [77]). In common with introgression studies in irises [77] studies on gametophytic competition in Zea mays [60] and Dianthus chinenesis [59] also suggest that faster growth of conspecific pollen tubes might be acting as a barrier to interspecific hybridization (cf. Glossary) $[59,80]$. Prefertilisation incompatibility (cf. Glossary) barriers can occur on the stigmatic surface or during the growth of the pollen tube in the style, in the ovary, in the ovules or in the embryo sac [50]. Prefertilisation incompatibility barriers in Populus sp. are known to be located primarily in the stylar tissues [102]. Special emphasis has been made on pollen tube-pistil interaction in $P$. nigra, revealing precise growth of pollen tube within the ovary [101], role of ABA in flower pedicel abscission due to zygotic interspecific incompatibility [52] and role of $\beta$-galactosidase activity associated with conspecific pollen tube growth [103]. Interspecific mixtures of viable incompatible and killed compatible (mentor/recognition) pollen have been used to achieve incompatible mating with variable success (reviewed in [102]). 


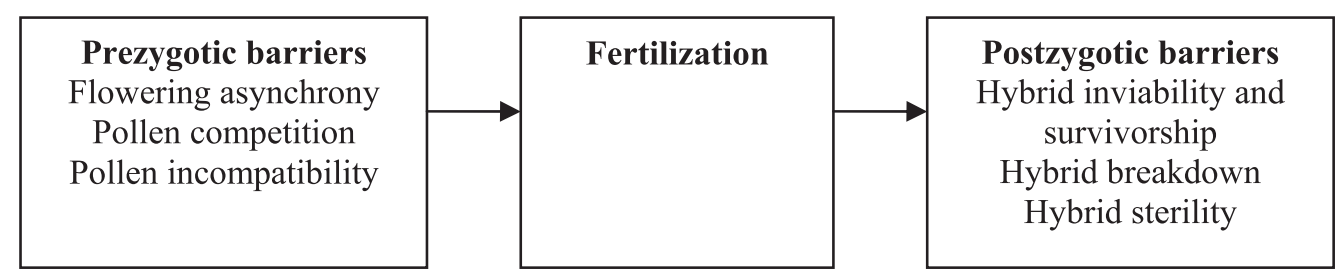

Figure 2. Reproductive isolation mechanisms in Populus.

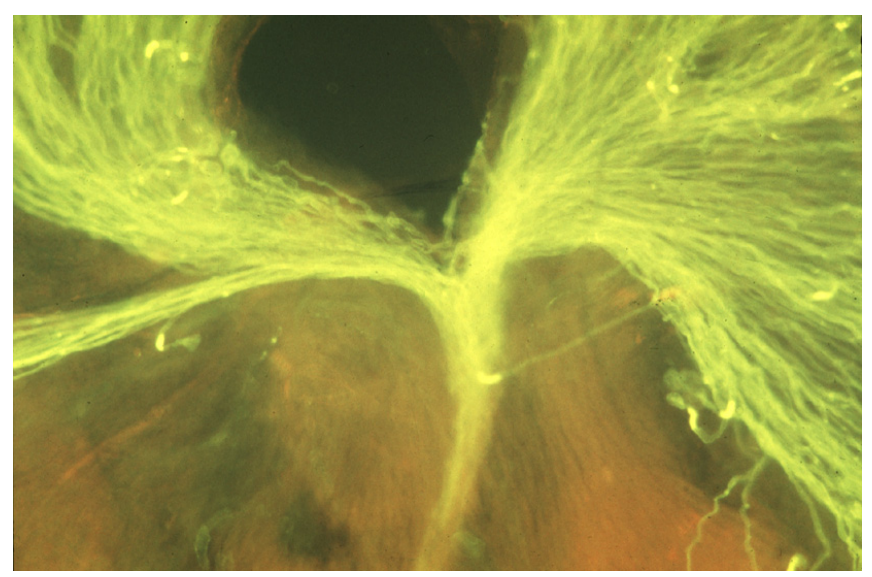

Figure 3. Pollen tube competition within the stigma of a Populus nigra flower. After germination of the numerous pollen grains on the stigmatic surface, the pollen tubes grow within the stigmatic tissues and compete to reach the stylodium (bottle neck) before reaching the ovarian cavity.

\subsection{Postzygotic barriers}

Common postmating reproductive barriers include hybrid sterility, hybrid weakness or inviability, and hybrid breakdown (cf. Glossary) in which first generations (F1) hybrids are vigorous (hybrid superiority due to heterosis), robust and fertile, but later generation hybrids are weak or inviable [77]. Poplar hybrids are characterised by reduced fertility relative to parental species, and significant lower pollen production and seed viability in $\mathrm{F}_{1}$ hybrids $[86,94]$. This has been observed in poplar hybrids growing in commercial plantations and natural zones of hybridization [94]. However, recent analyses have found that poplar hybrids are not uniformly unfit, but rather are genotypic classes that possess lower, equivalent or higher levels of fitness relative to their parental taxa. Schweitzer et al. [81] found that F-generations of $P$. fremontii S. Watson $\times P$. angustifolia James and backcross generations can be just as fit as the parent taxa. F-generations produced as many viable seed as $P$. angustifolia and backcross genotypes produced as many viable seeds as both parent taxa. Moreover, hybrids produced nearly two and four times as many ramets from root sprouts as $P$. angustifolia and $P$. fremontii, respectively. Extensive variability in viability and fertility is also observed within and between hybrid generations from the same interspecific cross. Therefore, extremely low fertility or viability of early-generation hybrids (e.g. $\mathrm{F}_{1}, \mathrm{~F}_{2}, \mathrm{BC}_{1}$ ) does not necessarily prevent

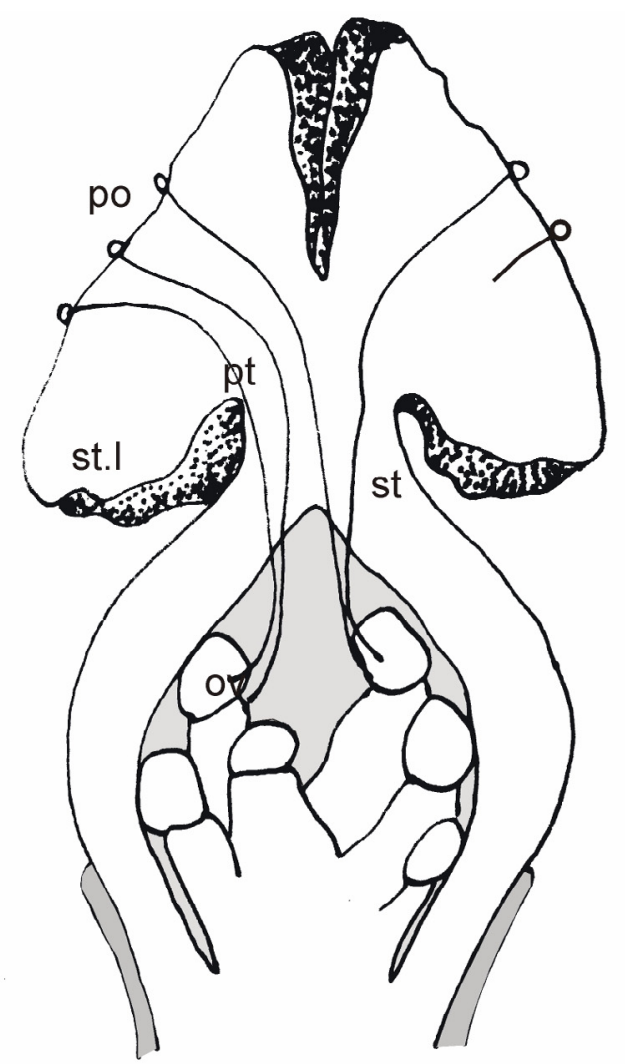

Figure 4. Diagrammatic representation of pollen tube competition on a Populus nigra flower. po: pollen grain, pt: pollen tube, st.l: stigmatic lobes, st: stylodium, ov: ovule. Adapted from [103].

extensive gene flow [5]. Detailed studies of the genetic basis of hybrid breakdown suggest that hybrid weakness appears to result from the break-up of co-adapted gene complexes (cf. Glossary) that affect fitness traits $[6,58,75,77]$. If many genes contribute to fitness traits, then much of the genome may be resistant to introgression because of linkage (cf. Glossary). These results also suggest that species genomes are often differentially permeable to introgression, where certain portions of the genome are open to the incorporation of alien alleles, but introgression is restricted in other parts of the genome $[58,76]$. Introgression may therefore be an important mechanism for the transmission of ecologically functional traits [6]. Different selection pressures for different genomic regions were also observed in Populus [6, 58]. The results of Martinsen et al. [58] 
Table II. Some molecular markers used in studies of introgressive hybridisation in Populus.

\begin{tabular}{|c|c|c|c|c|}
\hline Marker type & Mode of transmission & Mode of gene action & Level of variability & Ref. \\
\hline Isozymes & $\begin{array}{l}\text { Biparental } \\
\text { Nuclear }\end{array}$ & Codominance & Low to medium & $\begin{array}{r}{[10,11,47,48,64} \\
65,67,74,88,98]\end{array}$ \\
\hline Chloroplast microsatellites (cpDNA) & $\begin{array}{c}\text { Maternal } \\
\text { Pseudo-haploid cytoplasmatic }\end{array}$ & $\begin{array}{l}\text { Each cytotype is } \\
\text { expressed }\end{array}$ & Low & $\begin{array}{c}{[45,51,70,71,72,} \\
73,104]\end{array}$ \\
\hline $\begin{array}{l}\text { Restriction Fragment Length Polymorphisms } \\
\text { (RFLPs) of ribosomal RNA genes }\end{array}$ & $\begin{array}{l}\text { Biparental } \\
\text { Nuclear }\end{array}$ & Codominance & Medium to high & {$[21,22,33]$} \\
\hline Nuclear microsatellites (SSR) & $\begin{array}{l}\text { Biparental } \\
\text { Nuclear }\end{array}$ & Codominance & High & {$[37,92,97]$} \\
\hline $\begin{array}{l}\text { Amplified Fragment Length Polymorphism } \\
\text { (AFLP) }\end{array}$ & $\begin{array}{l}\text { Biparental } \\
\text { Nuclear }\end{array}$ & Dominance & High & {$[3,18,97,108]$} \\
\hline Sequence Tagged Site marker win3 (STS) & $\begin{array}{l}\text { Biparental } \\
\text { Nuclear }\end{array}$ & Codominance & Medium & {$[41,92,98]$} \\
\hline
\end{tabular}

indicate that the hybrid zone between natural populations of $P$. fremontii and $P$. angustifolia $(P . \times$ hinckleyana $=$ natural hybrid between $P$. fremontii $\times P$. angustifolia) located near the river Weber (Utah, USA), acts as an evolutionary filter, preventing the introgression of most genes but allowing others to introgress. Different introgression rates (localised introgression, slow-dispersed and fast-dispersed introgression) among genetic markers suggest that there are different selection pressures for different genomic regions. A few well dispersed, negative acting genes could impede the majority of the genome from introgression [58]. Because large DNA segments are more likely to carry such negative genes, backcrosses carrying large DNA segments, would be selected against. Consistent with this hypothesis, selective filtering of the genome appears to be most intense in the very earliest backcross generations (e.g. at the hybrid zone boundary) where the average introgressing segment is likely to be $25 \mathrm{cM}$ or larger [58]. The arrangement of genes and their action will have a major impact on the genomic pattern and rates of introgression [58]. If hybrid populations act as evolutionary filters, there are several important implications [58]. First, species barriers are maintained in the face of hybridization. Second, a strong filter should prevent the introgression of deleterious genes while allowing introgression of beneficial ones. Finally, a filter help explain the existence and long-term persistence of hybrid zones [58].

\section{DETECTION OF HYBRIDIZATION}

Based on morphological traits, it is not always possible to unambiguously detect introgressed genes in the offspring of a particular species. Individuals from hybrid swarms (cf. Glossary) that obtained most of their genes from one of the parental taxa are often morphologically indistinguishable from that parental taxon [2]. Furthermore, environmental influences on morphology and differences between juvenile and mature characters make it difficult to determine accurately the taxon of young poplar seedlings on the basis of morphological characters alone [2]. Molecular markers now provide helpful tools to assess introgression in plant populations. Over the years, the most conclusive evidence for introgression in Populus sp. has come from molecular data (Tab. II): initially from isozyme (cf.
Glossary) work [10, 47, 48, 64, 67] and more recently also from DNA data (e.g. [20, 41, 42, 45, 65, 88, 100, 104]). Finding true diagnostic alleles for each species require extensive sampling from both species' natural ranges, as alleles common in one species may be rare, but still present in the other [45]. Chloroplast and mitochondrial cytoplasmic markers (Tab. II) are maternal inherited in Populus [68] and are a useful complement to nuclear markers to study the direction of introgression [20]. $\mathrm{F}_{1}$-hybrids can be reliably identified with nuclear markers but it is more difficult to distinguish between $\mathrm{F}_{2}$, backcrosses and later-generation hybrids [13]. However, in Populus, interspecific natural hybridization among native species is geographically restricted and parental populations still exist [27, 29, 36, 94]. In contrast with interspecific natural hybridization, anthropogenic hybridization and introgression might have begun only recently so that to date, advanced generations of backcrosses among domesticated and native Populus taxa are unlikely. However, an enlarged set of nuclear and/or biochemical markers is desirable to estimate parent' species contributions to single clones and plants more accurately [45].

Several authors agree about the usefulness of the diagnostic isozyme systems LAP, PGM, PGI to differentiate between $P$. deltoides, $P$. nigra and $P . \times$ canadensis $[10,11,67,74,100]$. The enzyme loci Aco-3 and Mdh-3 were found diagnostic for differentiating between $P$. alba, $P$. tremula and their hybrids $(P . \times$ canescens) [69]. Species-specific markers in Populus have also been described based for ribosomal DNA [22, 33], mitochondrial DNA [7, 66], chloroplast DNA (e.g. [20, 45, 51, $70,83,104])$ and the STS nuclear gene marker win3 [41]. Recently, a microsatellite marker (WPMS09) [96] was found useful to differentiate between genes of $P$. deltoides and P. nigra [37, 100] (cf. Glossary).

Hybridization of native $P$. nigra with the cultivated $P$. nigra cv. 'Italica' and P. nigra cv. 'Thevestina' is more difficult to detect as they belong to the same species. Imbert \& Lefèvre [46] found for each of 6 SSR loci studied, alleles in natural populations of $P$. nigra along the river Drôme that were shared with the Lombardy poplar, although the frequency of these alleles was highly variable. They considered the most frequent alleles as common alleles of the species whereas the rarest alleles were considered to provide an upper estimate of possible 
hybridization with the Lombardy poplar [46]. The SSR locus WPMS09 [96] showed the lowest frequency of the two alleles shared with $P$. nigra cv. 'Italica' $(<0.05)$ [46].

\section{NATURAL HYBRIDIZATION AMONG NATIVE POPLAR SPECIES}

Despite the numerous barriers, hybridization is common in Populus. Natural poplar hybrids are regularly found wherever different species come into contact with one another [28, 29, $36,58]$. However, the extent of introgression can vary substantially depending on the species involved, the environment of the hybrid zone and the portion of the genome examined [58]. Hybridization between species of different sections is comparatively restricted. Only section Aigeiros and section Tacamahaca are freely intercrossable [28, 29]. These two sections, like others in the genus, differ somewhat in habitat as well as in range. Balsam poplars (Tacamahaca) are trees of boreal and montane habitats, while cottonwoods (Aigeiros) occupy lower elevations of middle latitudes. They are largely allopatric in Eurasia but are broadly sympatric in North America, with overlapping ecological preferences. They contact each other and hybridise primary where topographic diversity brings their distinctive habitats into proximity. Such localities, although widespread, are restricted (about 10-15 km) and populations containing hybrids represent a small fraction of all populations of each parent species. Most hybrids in the field appear to be first-generation crosses [28] although advancedgeneration hybrids were also observed [58, 94]. The hybrids show little tendency to invade the characteristic habitats of either of their parents but tend to remain in the hybridised habitat [28, 29]. Natural hybrid zones have existed between sympatric native poplar species for millennia, yet these species have retained their identities, with remarkably little introgression $[28,58]$. Rhymer and Simberloff [75] discuss that lack of fitness of $F_{1}$ hybrids, later generations, or backcrosses are evident in many stable hybrid zones. This is a form of outbreeding depression (cf. Glossary) and may result from chromosomal differences, the breakdown of co-adapted gene complexes or both. Hybrid zones also form at boundaries of narrow gradients between distinct habitats, so that each habitat favours one parental taxon, and hybrids are selected against in both [40]. There are exceptions to this ecological barrier to hybridization; in local areas the habitats of cottonwood and balsam poplar parents may be virtually indistinguishable and thus not limiting to the hybrids. This is probably the case with $P$. balsamifera L., P. deltoides, and P. $\times$ jackii Sarg. (natural hybrid of $P$. balsamifera and $P$. deltoides), in part of their broad range of sympatry [78]. In North America near the Weber River in Utah, $P$. fremontii hybridise with $P$. angustifolia where their distinctive habitats come into proximity. In the 13-km hybrid zone introgression is unidirectional; $\mathrm{F}_{1}$ hybrids only backcross with pure $P$. angustifolia (absence of hybrid $\times$ hybrid and hybrid $\times P$. fremontii crosses) [49]. This restricted hybridization process means that the hybrid zone is not selfperpetuating, and will presumably go extinct in the absence of a $P$. angustifolia population [49].

Whitham et al. [107] and Rotach [79] illustrated that hybrid poplar zones are dynamic centres of ecological and evolution- ary processes for plants and their associated communities. The intermediate genetic differences between the parental species will result in the greatest genetic variation in the hybrid zone, which in turn will have a positive effect on biodiversity [79, 107]. These natural zones of hybridization are unique and worthy of special efforts to promote their conservation and protection [58, 107]. This is particular the case in China, where ten different hybrid swarms have been registered so far [106].

\section{ANTHROPOGENIC HYBRIDIZATION}

Numerous exotic poplar species have been introduced into Europe as well as into the USA, Canada and China for the establishments of shelterbelts, windbreaks and wood production in urban, suburban and agricultural landscapes. As no published information exists concerning anthropogenic hybridization of Populus in China, we had to focus on examples from Europe and North America.

\subsection{North America}

Examples of non-native poplars introduced in North America are $P$. nigra, $P$. alba, $P$. $\times$ canadensis and hybrids between $P$. deltoides and $P$. trichocarpa (i.e. P. $\times$ generosa) $[25,94$, 110 ] and $P . \times$ petrowskyana (a hybrid of $P$. laurifolia Ledeb. $\times$ $P$. deltoides) [78]. P. alba L., the European white poplar, was introduced from Europe to North America in the early 18th century, and hybridises naturally with the native American aspens, Populus grandidentata Michaux and P. tremuloides Michaux. [84]. However, only $F_{1}$ hybrids resulting from natural hybridization between introduced $P$. alba and native $P$. grandidentata or $P$. tremuloides were found and no advanced generation hybrids or backcrosses were detected [84].

A female clone of $P . \times$ petrowskyana (often referred to as "Russian" poplar) was introduced and widely distributed in western Canada about 100 years ago [78]. This clone hybridises occasionally with the native species $P$. balsamifera and more frequently with $P$. deltoides cv. occidentalis and $P . \times$ jackii [78]. Eckenwalder [27] reports on a single locality in California at which native $P$. fremontii has apparently hybridised successfully with a female introduced $P$. nigra. The Lombardy poplar is widely planted in North America. It is quite fertile and capable of siring seeds with $P$. trichocarpa females even when the trees are separated by large distances [25]. However, despite a long history of extensive cultivation in proximity to native populations, there is no evidence for extensive introgression of Lombardy poplar in native populations in North-America $[25,94]$. This paucity of hybrids may be attributed to the sex of the introduced $P$. nigra. Its pollen may not be able to compete with pollen of $P$. deltoides or $P$. fremontii in fertilizing ovules of these species in natural populations (Baker, 1951, in [94]).

Occasionally, in North America non-native poplars colonise adjacent riparian corridors via asexual propagation, yet there are no reports of these species displacing native cottonwood populations [94]. Because of the limited size of plantations compared to wild stands in most area, plantation-derived 
propagules are usually greatly diluted with propagules from wild stands, including those located a short distance from plantations [25]. Other barriers like conspecific mating preference may also play a role in limiting anthropogenic hybridization [99].

\subsection{Europe}

The most common non-native poplars in Europe include: $P . \times$ canadensis, $P . \times$ generosa (cultivated hybrids between $P$. deltoides Marshall and P. trichocarpa), P. trichocarpa, $P$. deltoides, $P$. alba (non-native in North Europe), $P$. nigra cv. 'Italica' (Lombardy poplar) and P. nigra cv. 'Thevestina'.

In Europe in the eighteenth century, spontaneous hybridization between the introduced $P$. deltoides and the native $P$. nigra occurred, giving rise to the widely cultivated $P . \times$ canadensis [27]. While the activities on poplar breeding and cultivation rise in Europe, human activities in floodplain areas including agriculture, urbanisation and hydraulic engineering resulted in the habitat destruction and modification of the native black poplar. Moreover, clones of $P . \times$ canadensis were massively planted for wood production to replace the autochthonous black poplar resources on alluvial floodplains in many countries of the temperate regions. This resulted in a severe reduction in population size and habitat fragmentation of the European black poplar all over Europe. The situation in the United Kingdom and in Belgium illustrates the risk of species extinction in the margins of its range area. In these countries, black poplar is considered to be one of the rarest native trees $[19,100]$. However, only recently evidence for introgressive hybridization of $P . \times$ canadensis in the offspring of black poplar females was found [98]. In Belgium, genes of $P$. deltoides were detected in the open pollinated offspring of a black poplar female, surrounded by $P . \times$ canadensis hybrids and in the absence of conspecific males. This is the only study reporting on introgression in the offspring of black poplar and the results are in contrast with other studies, were no introgression of $P$. deltoides genes in the offspring of $P$. nigra females was found, even when flowering male trees of $P . \times$ canadensis were present in the vicinity [10, 41, 92]. The Belgian study [98] differs from the other studies by the fact that the female black poplars investigated were in the absence of conspecific males. In a mixed pollen cloud, pollen of $P$. nigra may be more successful than that from $P . \times$ euramericana in pollinating female black poplar [92, 100]. This hypothesis could be confirmed by controlled crossing experiments with interspecific pollen mixes (i.e. a mix of $P$. nigra and $P . \times$ canadensis pollen) suggesting conspecific pollen advantage [99]. However, if no pollen of the own species is present, $P$. nigra females can be pollinated successfully by pollen of $P . \times$ canadensis. Therefore, low levels of introgression from $P . \times$ canadensis are expected in natural populations of $P$. nigra where there are several male black poplars close to the female trees. This is confirmed by the results of the European research project EUROPOP were low levels of introgression was found in black poplar populations along the borders of six river systems (Danube, Drôme, Ebro, Rhine, Ticino and Usk) [54]. Also in France low levels of introgression of genes of $P$. deltoides in natural black poplar populations were found along the rivers Garonne [61] and Loire (Villar, pers. observations), and no alleles of $P$. deltoides and $P$. trichocarpa were detected in natural black poplar populations along the Drôme [46]. In contrast, genes of $P$. deltoides were detected in young poplar seedlings colonising the banks of the river Meuse in Belgium [99], the rivers Waal and Meuse in the Netherlands [12], the river Ebro in Spain [1] the river Danube in Austria [44, 51] and Hungary [14] and in natural black poplar populations located in the Czech Republic [10]. It is most likely that these introgressed seedlings originate from hybrid $\times$ hybrid crosses or from open pollinated $P$. $\times$ canadensis females $[1,11,12,14$, 43], These findings indicate that, although low levels of introgression are detected in natural black poplar populations, cultivated poplars are reproductive along several river systems in Europe and that they may compete with the native species in colonising new habitats. Some of the introgressed seedlings seemed to be well adapted as they survived the river dynamics over several years.

\section{CONSERVATION IMPLICATIONS}

Cases of hybridization appear to be relatively frequent in plants, and many taxa have been influenced by hybridization at some point in their history [105]. The numerous barriers to hybridization including hybrid breakdown, reduced hybrid fertility, and post-zygotic reproduction barriers are paradoxical in light of the widespread occurrence of natural hybrids among native poplar species. This is due to the fact that successful establishment of hybrid populations is determined by events that, in many organisms, occur only rarely [4]. This establishment may initially be nonadaptive, or even maladaptive for the hybridising pairs, but may lead to adaptive evolution (cf. Glossary) through the production of hybrid genotypes that are more fit than their parents in the parental or novel habitats [4]. Therefore, hybridization with or without introgression, even when occurring rarely, can have important consequences for evolution and conservation biology of native poplar populations. This is particularly true for anthropogenic hybridization and for rare species that come into contact with other species that are more abundant [75]. Rhymer and Simberloff [75] have concluded that the severity of this problem has been underestimated by conservation biologists. The increasing pace of the three interacting human activities that contribute most to increased rates of hybridization (introductions, fragmentation and habitat modification) suggests that this problem will become even more serious [75]. This is particularly the case for Populus, a forest tree of considerable economic importance [93]. Several studies have demonstrated that domesticated poplars are capable of spontaneously mating with their wild relatives under field conditions and that hybridization can vary considerably with the specific populations involved [10, 44, 46, 61].

When wild poplar stands are very small compared to widespread hybrid poplar plantations, the wild populations may go extinct through genetic assimilation. Individuals in small, isolated populations in contact with other taxa are much more likely to hybridise if only because of the difficulty of finding mates of the same species. This is the case for isolated native populations of P. nigra at the Northern margin of its geographical distribution area [92, 100] and at its Eastern margin in China where $P$. nigra freely hybridise with $P$. laurifolia (Villar, pers. observations, [82]). There, introduced hybrid poplars may 
be able to outperform native poplar populations in the short term (a few generations). Once hybridization has begun, it is difficult to stop, especially if hybrids are fertile and mate both among themselves and with parental individuals [2], as seemed to be the case in Populus [99]. Eliminating the domesticated poplars is not an option because of the economic importance of cultivated hybrid poplar plantations. In this case, effort should focus on maintaining and expanding the remaining pure native populations [2]. Probably, the best long-term solution here is habitat restoration in combination with reforestation programmes.

When natural populations are large compared to cultivated poplar plantations, as is the case in France along the studied rivers Loire, Allier and Drôme anthropogenic introgression seems to be restricted ([46], Villar, unpublished data). However, in this case, monitoring of the process of hybridization is of crucial importance in order to avoid that the proportion of hybrid individuals increases progressively. The competitive ability and initial frequency are factors that have a strong effect on risk of extinction through hybridization [109]. As for most pioneer species, competition for resources becomes important soon after germination and thus selection might occur at a very early stage [46]. Population size, effective population size and potential introgression should be monitored across multiple generations in order to estimate extinction risk. They should be considered in management and conservation plans.

\section{CONCLUSION AND FUTURE RESEARCH NEEDS}

There is still much work to be done before we fully understand the risks that are associated with gene flow between cultivated poplars and their wild relatives. We know that anthropogenic introgressive hybridisation occurs albeit it is limited by natural genetic barriers and its frequency depends on the local population size and the abundance of the cultivated poplars. In summary, the risk of natural hybridization between cultivated poplars and their wild relatives must be analysed on a case-by-case basis. Situations where cultivated poplars outnumber very small native poplar populations are likely to be most problematic. The issue of introgression in Populus will continue to receive much attention as it is also important for assessing the potential impacts of transgenic poplar plantations $[90,91]$. More diagnostic, species specific molecular markers and knowledge on their genomic distribution are needed to allow a more accurate and rapid assessment method to quantify introgression. To help understand the consequences of introgression, studies on reproductive properties like fertility, colonisation capacity and competitive ability of cultivated poplars compared to their wild relatives are needed. When hybrid seedlings can not effectively compete in the field with seedlings of the native species, introgression will not occur. Also, a better understanding of the genomic distribution and function of genes that contribute to fitness traits and the detection of regions in the genome that are less prone to introgression would allow a better understanding of introgression and subsequent consequences for the native poplar populations [87]. The data and skills accumulated regarding these questions may also prove helpful in addressing the issue of transgene flow in Populus.

\section{Glossary*}

Adaptive evolution: the process of change in a population driven by variation in reproductive success that is correlated with heritable variation in a trait.

AFLP: abbreviation for amplified fragment length polymorphism. A type of DNA marker, generated by the PCR amplification of restriction endonuclease treated DNA. A small proportion of all restriction fragments is amplified in any one reaction, so that AFLP profiles can be analysed by gel electrophoresis. This has the important characteristic that many markers can be generated with relatively little effort.

Anthropogenic hybridization: the movement of genes between species or taxa caused or produced by human action.

Backcross $\left(\mathbf{B C}_{1}, \mathbf{B C}_{2}\right)$ : the offspring of a cross between a hybrid and one of its parents. The subscript number represents the number of generations that have been crossed in this fashion.

Chloroplast DNA (cpDNA): the DNA present in the chloroplast.

Cladoptosis: the shedding of twigs by abscission.

Co-adapted gene complexes: particular combinations of genes at multiple loci that interact to confer higher fitness relative to other genotypes.

Conspecific: belonging to the same species.

Dioecious: organisms in which the male and female sex are in separate individuals.

EUFORGEN: European Forest Genetic Resources Programme.

EUROPOP: Research project "Genetic Diversity in River Populations of European Black Poplar for evaluation of biodiversity, conservation strategies, nature development and genetic improvement". This project was carried out with financial support from the Commission of the European Communities, Agriculture and Fisheries (FAIR) specific RTD programme, PL97-3386

$\mathbf{F}_{1 \text { (2): }}$ : the first (second) generation of a cross.

Gene flow: exchange from genes among populations because of successful reproduction by migrants.

Genetic swamping: rapid increase in frequency of an introduced genotype (or introduced allele) that might lead to replacement of local genotypes; caused by a numerical and/or fitness advantage.

Hybrid breakdown: reduction in fitness of hybrids relative to parents caused by disruption of co-adapted gene complexes via recombination.

Hybrid swarm: a population consisting of hybrids and various types of backcrosses between two or more intercrossing sympatric species.

Hybridization: the process of forming a hybrid by cross pollination.

Incompatibility: selectively-restricted mating competence, which limits fertilization, such as lack of proper functions by otherwise normal pollen grains or certain pistils, a condition that may be caused by a variety of factors.

Interspecific hybridization: the movement of genes between species.

Introgression: the infiltration of germplasm from one species into another through repeated backcrossing of the hybrids to the parental species.

Isozyme: a genetic variant of an enzyme. Isozymes for a given enzyme share the same function, but may differ in level of activity, as a result of minor differences in their amino acid sequence.

LAP, PGM, PGI: abbreviations for the isozymes leucine amino peptidase, phosphoglucomutase and phosphogluco isomerase, respectively.

Linkage: the greater association in inheritance of two or more nonallelic genes than is to be expected from independent assortment.

Microsatellite or Simple Sequence Repeat (SSR): a segment of DNA characterized by a variable number of copies (typically 5-50) of a sequence of around 5 or fewer bases.

Mitochondrial DNA: a circular DNA found in mitochondria.

Outbreeding depression: reduction in mean population fitness resulting from hybridization between genetically distinct individuals or populations of the same species; detected in $\mathrm{F}_{1}$ or subsequent generations.

Outcrosser: an individual that must be cross-pollinated to successfully complete generative reproduction.

*Adapted from FAO Glossary of Biotechnology for Food and Agriculture, http://www.fao.org/biotech/ 
Primordia: a group of cells that represents the initial stages in development of a plant organ.

Quantitative genetics: the discipline that studies changes in traits in populations when many genes affect one trait.

RFLP: abbreviation for restriction fragment length polymorphism. A class of genetic marker based on the detection of variation in the length of restriction fragments generated when DNA is treated with restriction endonucleases.

Ribosomal DNA: the coding locus for ribosomal RNA.

STS: abbreviation for sequence-tagged site. Short unique DNA sequence (200-500 bp long) that can be amplified by PCR and is thus tagged to the site on the chromosome from which it was amplified.

Acknowledgements: The authors gratefully acknowledge the members of the EUFORGEN Populus nigra Network, particularly Berthold Heinze, Georg von Wuehlisch, Sven M.G. de Vries, Peter Rotach and Nuria Alba. The authors also thank Peter Breyne and two anonymous reviewers for their useful comments to a previous version of the manuscript.

\section{REFERENCES}

[1] Agúndez D., Fluch S., Maestro C., Alba N., Introgression genética procedente de plantaciones de híbridos en rodales naturales de Populus nigra, Actas del III Congreso Forestal Español, Vol. II, 2001, pp. 546-552.

[2] Allendorf F.W., Leary R.F., Spruell P., Wenburg J.K., The problems with hybrids: setting conservation guidelines, Trends Ecol. Evol. 16 (2001) 613-622.

[3] Arens P., Coops H., Jansen J., Vosman B., Molecular genetic analysis of black poplar (Populus nigra L.) along Dutch rivers, Mol. Ecol. 7 (1998) 11-18.

[4] Arnold M.L., Natural Hybridization and Evolution, Oxford University Press, Oxford, 1997.

[5] Arnold M.L., Kentner E.K., Johnston J.A., Cornman S., Bouck A.C., Natural hybridisation and fitness, Taxon 50 (2001) 93-104.

[6] Bailey J.K., Schweitzer J.A., Rehill B.J., Lindroth R.L., Martinsen G.D., Whitham T.G., Beavers as molecular geneticists: A genetic basis to the foraging of an ecosystem engineer, Ecology 85 (2004) 603-608.

[7] Barrett J.W., Rajora O.P., Yeh F.C.H., Dancik B.P., Strobeck C., Mitochondrial DNA variation and relationships of Populus species, Genome 36 (1993) 87-93.

[8] Barsoum N., Regeneration - requirements and promotion measures, in: Lefèvre F., Barsoum N., Heinze B. et al. (Eds.), EUFORGEN Technical Bulletin: In situ conservation of Populus nigra, International Plant Genetic Resources Institute, Rome, 2001, pp. 16-24.

[9] Barsoum N., Relative contributions of sexual and asexual regeneration strategies in Populus nigra and Salix alba during the first years of establishment on a braided gravel bed river, Evol. Ecol. 15 (2002) 255-279.

[10] Benetka V., Mottl J., Vacková K., Pospísková M., Dubský M., Estimation of the introgression level in Populus nigra L. populations by means of isozyme gene markers, Silvae Genet. 48 (1999) 218-223.

[11] Benetka V., Vacková K., Bartáková I., Popísková M., Rasl M., Introgression in black poplar (Populus nigra L. ssp. P. nigra) and its transmission, J. For. Sci. 48 (2002) 115-120.

[12] Beringen R., Natuurlijke verjonging en hybridisatie bij populieren, Gorteria 24 (1998) 139-147.
[13] Boecklen W.J., Howard D.J., Genetic analysis of hybrid zones: Number of markers and power of resolution, Ecology 78 (1997) 2611-2616.

[14] Bordács S., Borovics A., Bach I., Genetic diversity of natural populations and gene bank of Black poplar in Hungary, in: van Dam B.C., Bordács S. (Eds.), Genetic diversity in river populations of European Black poplar - Implications for riparian eco-system management, Csiszár, Nyomda, Budapest, 2002, pp. 93-106.

[15] Braatne J.H., Rood S.B., Heilman P.E., Life history, ecology, and conservation of riparian cottonwoods in North America, in: Stettler R.F., Bradshaw H.D. Jr., Heilman P.E., Hinckley T.M. (Eds.), Biology of Populus, NRC Research Press, Ottawa, 1996, pp. 57-58.

[16] Bradshaw H.D., Ceulemans R., Davis J., Stettler R.F., Emerging model systems: Poplar (Populus) as a model forest tree, J. Plant Growth Regul. 19 (2000) 306-313.

[17] Cagelli L., Lefèvre F., The conservation of Populus nigra L. and gene flow with cultivated poplars in Europe, For. Genet. 2 (1995) 135-144.

[18] Chauhan N., Negi M.S., Sabharwal V., Khurana D.K., Lakshmikumaran M., Screening interspecific hybrids of Populus (P. ciliata $\times$ maximowiczii) using AFLP markers, Theor. Appl. Genet. 108 (2004) 951-957.

[19] Cottrell J.E., Tabbener H.E., Forrest G.I., Distribution of variation in British Black Poplar: the role of human management, in: van Dam B.C., Bordács S. (Eds.), Genetic diversity in river populations of European Black poplar - Implications for riparian eco-system management, Nyomda Ltd., Budapest, 2002, pp. 73-84.

[20] Cottrell J.E., Tabbener H.E., Milner A., Connolly T., Sing L., Lefèvre F., Achard P., Bordács S., Gebhardt K., Vornam B., Smulders R., Vanden Broeck A., Storme V., Boerjan W., Castiglione S., Fossati T., Alba N., Agúndez D., Fluch S., Krystufek V., Burg K., Bovenschen J., van Dam B., Chloroplast DNA haplotypes of 637 trees of Populus nigra L. held in ex situ conservation genebanks in seven European countries and their possible postglacial migration routes, For. Ecol. Manage. 206 (2005) 71-90.

[21] D'Ovido R., Mugnozza Scarascia G., Tanzarella Oronzo A., Ribosomal RNA genes structure in some Populus spp. (Salicaceae) and their hybrids, Plant Syst. Evol. 173 (1990) 187-196.

[22] D'Ovido R., Mugnozza Scarascia G., Tanzarella Oronzo A., rDNA cloning and rapid hybrid identification in Populus spp. (Salicaceae), Plant Syst. Evol. 177 (1991) 165-174.

[23] de Vries S.M.G., Turok J., Introduction, in: Lefèvre F., Barsoum N., Heinze B. et al. (Eds.), EUFORGEN Technical Bulletin: In situ conservation of Populus nigra, International Plant Genetic Resource Institute, Rome, 2001, pp. 5-8.

[24] Dickmann D.I., An overview of the genus Populus, in: Dickmann E.I., Isebrands J.G., Eckenwalder J.E., Richardson J. (Eds.), Poplar Culture in North America, NRC Research Press, Ottawa, 2001, pp. $1-42$.

[25] DiFazio SP., Measuring and modelling gene flow from hybrid poplar plantations: Implications for transgenic risk assessment, Ph.D. thesis, Oregon State University, Oregon, 2002.

[26] DiFazio S.P., Slavov G.T., Burczyk J., Leonardi S., Strauss S.H., Gene Flow from tree plantations and implications for transgenic risk assessment, in: Walter C., Carson M. (Eds.), Plantation Forest Biotechnology for the 21st Century, Research Signpost, 2004, pp. 405-422.

[27] Eckenwalder J.E., Populus $\times$ inopina Hybr. Nov. (Salicaceae), a natural hybrid between the native North American $P$. fremontii S. Watson and the introduced Eurasian P. nigra L., Madroño 29 (1982) 67-78.

[28] Eckenwalder J.E., Natural intersectional hybridization between North American species of Populus (Salicaceae) in section Ageiros and Tacamahaca. II. Taxonomy, Can. J. Bot. 62 (1984) 325-335. 
[29] Eckenwalder J.E., Natural intersectional hybridization between North American species of Populus (Salicaceae) in sections Aigeiros and Tacamahaca. III. Paleobotany and evolution, Can. J. Bot. 62 (1984) 336-342.

[30] Eckenwalder J.E., Systematics and evolution of Populus, in: Stettler R.F., Bradshaw H.D., Heilman P.E. Jr., Hinckley T.M. (Eds.) Biology of Populus, NRC Research Press, Ottawa, 1996, pp. 7-32.

[31] Ellstrand C.N., Current knowledge of gene flow in plants: implications for transgene flow, Trans. Roy. Soc. London 358 (2003) $1163-1170$.

[32] Ellstrand N.C., Gene flow by pollen: implications for plant conservation genetics, Oikos 63 (1992) 77-86.

[33] Faivre-Rampant P., Jeandroz S., Lefèvre F., Lemoine M., Villar M., Berville A., Ribosomal DNA Studies in poplars: Populus deltoides, Populus nigra, Populus trichocarpa, P. maximowiczii and P. alba, Genome 35 (1992) 733-740.

[34] FAO. International Poplar Commission, International register of populus cultivars, http://caroline.agro.ucl.ac.be/efor.

[35] Farmer Jr. R.E., The genecology of Populus, in: Stettler R.F., Bradshaw H.E. Jr., Heilman P.E., Hinckley T.M. (Eds.), Biology of Populus, NRC Research Press, Ottawa, 1996, pp. 33-55.

[36] Floate K.D., Extent and patterns of hybridization among the three species of Populus that constitute the riparian forest of southern Alberta, Canada, Can. J. Bot. 82 (2004) 253-264.

[37] Fossati T., Grassi F., Sala F., Castiglione S., Molecular analysis of natural populations of Populus nigra L. intermingled with cultivated hybrids, Mol. Ecol. 12 (2003) 2033-2043.

[38] Galloway G., Worrall J., Cladoptosis: a reproductive strategy in black cottonwood? Can. J. For. Res. 9 (1979) 122-125.

[39] Guilloy-Froget H., Évaluation des conditions favorables à l'établissement de Populus nigra et Salix alba en milieu riverain, Ph.D. thesis, Toulouse, France, 2002.

[40] Harrison R.G., Hybrid and hybrid zones: historical perspective, in: Harrison R.G. (Ed.), Hybrid zones and the evolutionary process, Oxford University Press, Oxford, 1993, pp. 3-12.

[41] Heinze B., A PCR Marker for a Populus deltoides allele and its use in studying introgression with native European Populus nigra, Belg. J. Bot. 129 (1997) 123-130.

[42] Heinze B., Biochemical and molecular genetic methods available for the characterization of Populus nigra L., in: Turok J., Lefèvre F., de Vries S., Alba N., Heinze B. (Eds.), Populus nigra Network Report of the fourth meeting, 3-5 October 1997, Geraardsbergen, Belgium, IPGRI, Rome, 1998, pp. 42-61.

[43] Heinze B., Die Schwarzpappel in Österreich, Allg. Forst-Z. 5, 1998.

[44] Heinze B., Erhaltung der Schwarzpappel in Österreich-forstwirtschafliche, genetische und ökologische Aspekte, FBVA-Berichte Nr. 106, Forstliche Bundesversuchsanstalt Wien, Wien, 1998.

[45] Heinze B., PCR-Based chloroplast DNA assays for the identification of native Populus nigra and introduced poplar hybrids in Europe, For. Genet. 5 (1998) 31-38.

[46] Imbert E., Lefèvre F., Dispersal and gene flow of Populus nigra (Salicaceae) along a dynamic river system, J. Ecol. 91 (2003) 447456.

[47] Janssen A., Unterscheidung der beiden Schwarzpappelarten Populus nigra L. und $P$. deltoides Marsh. sowie ihrer Arthybride $P . \times$ euramericana (Dode) Guinier met Hilfe von Isoenzymmustern, Holzzucht 51 (1997) 17-23.
[48] Janssen A., Artbestimmung von Schwarzpappeln (Populus nigra L.) mit Hilfe von Isoenzymmustern und Überprüfung der Methode an Altbäumen, Absaaten von kontrollierten Kreuzungen und freien Abblüten sowie Naturverjüngungen. [Species determination of black poplar (Populus nigra L.) based on isozymes and isozyme analysis of black poplar trees, half-sib offsprings and full sib progenies originating from controlled crosses], in: Weisgerber H., Janssen A. (Eds.), Die Schwarzpappel, Hessischen Landesanstalt für Forsteinrichtung, Waldforschung und Waldökologie, 1998, pp. 32-42.

[49] Keim P., Paige K.N., Whitham T.G., Lark K.G., Genetic analysis of an interspecific hybrid swarm of Populus: Occurrence of unidirectional introgression, Genetics 123 (1989) 557-565.

[50] Knox R.B., Willing R.R., Pryor L.D., Interspecific hybridization in poplars using recognition pollen, Silvae Genet. 21 (1972) 65-69.

[51] Krystufek M.V., Population genetic analysis of Populus nigra in Austria using nuclear and chloroplast DNA markers, Ph.D. thesis, University of Wien, Wien, 2001.

[52] Label P., Imbault N., Villar M., ELISA Quantitation and GC-MS identification of abscisic acid in stigma, ovary and pedicel of pollinated poplar flowers (Populus nigra L.), Tree Physiol. 14 (1994) 521-530.

[53] Lefèvre F., Human impacts on forest genetic resources in the temperate zone: an update review, For. Ecol. Manage. 197 (2004) 257271.

[54] Lefèvre F., Bordács S., Cottrell J., Gebhardt K., Smulders M.J.M., Vanden Broeck A., Vornam B., van Dam B.C., Recommendations for riparian ecosystem management based on the general frame defined in EUFORGEN and results from EUROPOP, in: B.C. van Dam, S. Bordács (Eds.), Genetic diversity in river populations of European black poplar, Implications for riparian eco-system management, Proceedings of an international symposium held in Szeksárd, Hungary from 16-250 May, 2001, Csiszár Nyomda Ltd., Budapest, 2002, pp. 157-162.

[55] Lefèvre F., Kajba D., Heinze B., Rotach P., de Vries S.M.G., Turok J., Black poplar: A model for gene resource conservation in forest ecosystems, For. Chron. 77 (2001) 239-244.

[56] Legionnet A., Lefèvre F., Genetic variation of the riparian pioneer tree species Populus nigra L. 1. Study of population structure based on isozymes, Heredity 77 (1996) 629-637.

[57] Levin D.A., Francisco-Ortega J., Jansen R.K., Hybridization and the extinction of rare plant species, Conserv. Biol. 10 (1996) 10-16.

[58] Martinsen G.D., Whitham T.G., Turek R.J., Keim P., Hybrid populations selectively filter gene introgression between species, Evolution 55 (2001) 1325-1335.

[59] Mulcahy D., Mulcahy G., The influence of gametophytic competition on sporophytic quality in Dianthus chinensis, Theor. Appl. Genet. 46 (1975) 277-280.

[60] Mulcahy D.L., A Correlation between gametophytic and sporophytic characteristics in Zea mays L., Science 171 (1971) 11551156.

[61] Muller E., Guilloy-Froget H., Barsoum N., Brocheton L., Populus nigra L. in the Garonne valley: legacy of the past and present constraints, C.R. Biol. 325 (2002) 1129-1141.

[62] OECD. Consensus document on the biology of Populus L. (poplars), Organisation for Economic Co-operation and Development, Series on Harmonization of Regulatory Oversight in Biotechnology No. 16, Paris, 2000.

[63] Rajora O.P., Pollen competition among Populus deltoides Marsh. $P$. nigra L. and P. maximowiczii Henry in fertilizing P. deltoides ovules and siring its seed crop, Sex. Plant Reprod. 2 (1989) 90-96.

[64] Rajora O.P., Genetics of allozymes in Populus deltoides Marsh., $P$. nigra L., and P. maximowiczii Henry, J. Heredity 81 (1990) 301308. 
[65] Rajora O.P., Marker allozyme genes and alleles for differentiation of Populus deltoides, P. nigra, P. maximowiczii, and their interspecific hybrids, Can. J. Bot. 68 (1990) 990-998.

[66] Rajora O.P., Barrett J.W., Dancik B.P., Strobeck C., Maternal transmission of mitochondrial DNA in interspecific hybrids of Populus, Curr. Genet. 22 (1992) 141-145.

[67] Rajora O.P., Dancik B.P., Allozyme variation and inheritance in leaves of Populus deltoides, $P$. nigra, $P$. maximowiczii and $P . \times$ canadensis in comparison to those in root tips, Silvae Genet. 41 (1992) 289-292.

[68] Rajora O.P., Dancik B.P., Chloroplast DNA inheritance in Populus, Theor. Appl. Genet. 84 (1992) 280-285.

[69] Rajora O.P., Dancik B.P., Genetic characterization and relationships of Populus alba, P. tremula and P. $\times$ canescens, and their clones, Theor. Appl. Genet. 84 (1992) 291-298.

[70] Rajora O.P., Dancik B.P., Chloroplast DNA variation in Populus. I. Intraspecific restriction fragment diversity within Populus deltoides, P. nigra and P. maximowiczii, Theor. Appl. Genet. 90 (1995) 317-323.

[71] Rajora O.P., Dancik B.P., Chloroplast DNA variation in Populus. II. Interspecific restriction fragment polymorphisms and genetic relationships among Populus deltoides, $P$. nigra, $P$. maximowiczii, and $P . \times$ canadensis, Theor. Appl. Genet. 90 (1995) 324-330.

[72] Rajora O.P., Dancik B.P., Chloroplast DNA variation in Populus. III. Novel chloroplast DNA variants in natural $P . \times$ canadensis hybrids, Theor. Appl. Genet. 90 (1995) 331-334.

[73] Rajora O.P., Rahman M.H., Microsatellite DNA and RAPD fingerprinting, identification and genetic relationships of hybrid poplar (Populus $\times$ canadensis) cultivars, Theor. Appl. Genet. 106 (2003) 470-477.

[74] Rajora O.P., Zsuffa L., Allozyme divergence and evolutionary relationships among $P$. deltoides, $P$. nigra and $P$. maximowiczii, Genome 33 (1990) 44-49.

[75] Rhymer J.M., Simberloff D., Extinction by hybridization and introgression, Annu. Rev. Ecol. Syst. 27 (1996) 83-109.

[76] Rieseberg L.H., Burke J.M., A genic view of species integration, J. Evol. Biol. 14 (2001) 883-886.

[77] Rieseberg L.H., Carney S.E., Plant Hybridization, New Phytol. 140 (1998) 599-624.

[78] Ronald W.G., Steele J.W., Biosystematics of the genus Populus. III. Naturally occurring Manitoba hybrids of introduced $P . \times$ petrowskyana with native $P$. deltoides var. occidentalis and $P$. balsamifera, Can. J. Bot. 52 (1974) 1883-1887.

[79] Rotach P., Poplars and Biodiversity, in: Koskela J., de Vries S.M.G., Kajba D., Wuehlisch G. (Compilers), Populus nigra Network, Report of the seventh meeting (25-27 October 2001, Osijek, Croatia) and the eight meeting (22-24 May 2003, Treppeln, Germany), IPGRI, Rome, pp. 79-100.

[80] Sari Gorla M., Bellintani R., Ottaviano E., Competitive ability of maize pollen. Interaction between genotypes of pollen and stylar tissues, Maydica 21 (1976) 77-88.

[81] Schweitzer J.A., Martinsen G.D., Whitham T.G., Cottonwood hybrids gain fitness traits of both parents: A mechanism for their long-term persistence? Am. J. Bot. 89 (2002) 981-990.

[82] Shu WY., Poplar stand investigation in North Xinjiang, Ertix river and Ulungur rivers (English abstract from a Chinese working report), Chinese Academy of Forestry, internal report 1982: 9, 1982.

[83] Smith R.L., Systma K.J., Evolution of Populus nigra (sect. Aigeiros): introgressive hybridization and the chloroplast contribution of Populus alba (sect. Populus), Am. J. Bot. 77 (1990) 1176-1187.
[84] Spies T.A., Barnes B.V., A Morphological analysis of Populus alba, $P$. grandidentata and their natural hybrids in Southeastern Michigan, Silvae Genet. 30 (1982) 102-106.

[85] Stanton B.J., Villar M., Controlled reproduction of Populus, in: Stettler R.F., Bradshaw H.D. Jr., Heilman P.E., Hinckley T.M. (Eds.), Biology of Populus, NRC Research Press, Ottawa, 1996, pp. 113-138.

[86] Stettler R.F., Zsuffa L., Wu R., The role of hybridization in the genetic manipulation of Populus, in: Stettler R.F., Bradshaw H.D. Jr., Heilman P.E., Hinckley T.M. (Eds.), Biology of Populus, NRC Research Press, Ottawa, 1996, pp. 87-112.

[87] Stewart C.N. Jr., Halfhill M.D., Warwick S.I., Transgene introgression from genetically modified crops to their wilde relatives, Nature Rev. Genet. 4 (2003) 806-817.

[88] Storme V., Vanden Broeck A., Ivens B., Halfmaerten D., Van Slycken J., Castiglione S., Grassi F., Fossati T., Cottrell J.E., Tabbener H.E., Lefèvre F., Saintagne C., Fluch S., Krystufek V., Burg K., Bordács S., Gebhardt K., Vornam B., Pohl A., Alba N., Agúndez D., Bovenschen J., van Dam B.C., van der Schoot J., Vosman B., Boerjan W., Smulders M.J.M., Ex-situ conservation of Black poplar in Europe: genetic diversity in nine gene bank collections and their value for nature development, Theor. Appl. Genet. 108 (2004) 969-981.

[89] Strauss S., Report of the poplar working group, in: Traynor P., Westwood J.H. (Eds.), Proc. of the workshop on ecological effects of pest resistance genes in managed ecosystems, Bethesda, Maryland, http://www.isb.vt.edu/cfdocs/proceedings.cfm. 99, 1999.

[90] Strauss S.H., Brunner A.M., Busov V.B.C.M.A., Meilan R., Ten lessons from 15 years of transgenic Populus research, Forestry 77 (2004) 455-465.

[91] Svalov G.T., Difazio S.P., Strauss S.H., Gene flow in forest trees: From empirical estimates to transgenic risk assessment, Paper presented at the Scientific Methods Workshop Ecological and Agronomic Consequences of Gene Flow from Transgenic Crops to Wild Relatives, March 2002, Columbus, Ohio, USA, http://wwwdata.forestry.oregonstate.edu./tgbb/publications/Strauss_2002_Ohio.pdf.

[92] Tabbener H.E., Cottrell J.E., The use of microsatellite markers to study paternity in seedlings produced by a range of poplar species, For. Ecol. Manage. 179 (2003) 363-376.

[93] Taylor G., Populus: Arabidopsis for Forestry. Do we need a model tree? Ann. Bot. 90 (2002) 681-689.

[94] US Environmental Protection Agency, Biological aspects of hybrid poplar cultivation on floodplains in Western North America, A Review, Office of Ecosystems and Communities, US Environmental Protection Agency, Seattle, EPA Document No. 910-R-99-002, 1999.

[95] Van Dam BC, Bordács S. (Eds.), Genetic diversity in river populations of European Black poplar. Implications for riparian eco-system management, Csiszár Nyomda Ltd., Budapest, 2002.

[96] Van der Schoot J., Pospísková M., Vosman B., Development and characterization of microsatellite markers in black poplar (Populus nigra L.), Theor. Appl. Genet. 101 (2000) 317-322.

[97] Vanden Broeck A., Potential gene flow between native European black poplar (Populus nigra L.) and cultivated poplars in Belgium, Ph.D. thesis, University Ghent, Gent, 2004.

[98] Vanden Broeck A., Storme V., Cottrell J.E., Boerjan W., Van Bockstaele E., Quataert P., Van Slycken J., Gene flow between cultivated poplars and native black poplar (Populus nigra L.): A case study along the river Meuse on the Dutch-Belgian border, For. Ecol. Manage. 197 (2004) 307-310.

[99] Vanden Broeck A., Quataert P., Roldán-Ruiz I., Van Bockstaele E., Van Slycken J., Pollen competition in P. nigra females revealed by microsatellite markers, For. Genet. 10 (2003) 219-227. 
[100] Vanden Broeck A.H., Storme V., Cox K., Quataert P., Ivens B., Hostyn V., Haflmaerten D., Van Slycken J., Boerjan W., Mating system of Populus nigra in a mixed poplar stand composed of $P$. nigra, P. deltoides and P. $\times$ euramericana, in: van Dam B.C., Bordács S. (Eds.), Genetic diversity in river populations of European black poplar - Implications for riparian eco-system management, Csiszár Nyomda, Budapest, 2002, pp. 53-60.

[101] Villar M., Incompatibilité interspecifique chez Populus: Approches physiologique et biochimique, Ph.D. thesis, Université Claude Bernard, Lyon I, France, 1987.

[102] Villar M., Gaget-Faurobert A., Mentor effects in pistil-mediated pollen-pollen interactions, in: Hivanna K.R., Sawhney V.K. (Eds.), Pollen Biotechnology for crop production and improvement, Cambridge University Press, Cambridge, 1997, pp. 315-332.

[103] Villar M., Gaget M., Rougier M., Dumas C., Pollen-pistil interactions in Populus: $\beta$-galactosidase activity associated with pollentube growth in the crosses $P$. nigra $\times P$. nigra and $P$. nigra $\times$ P. alba, Sex. Plant Reprod. 6 (1993) 249-256.

[104] Vornam B., Herzog S., Preisigmuller R., Hattemer H.H., Restriction-Fragment-Length-Polymorphisms of a chloroplast photosystem-II gene from poplar and their use for species identification, Genome 37 (1994) 747-750.

[105] Wang X.-R., Szmidt A.E., Molecular markers in population genetics of forest trees, Scand. J. For. Res. 16 (2001) 199-220.
[106] Weisgerber H., Kownatzki D., Mussong M., Natural poplar resources in China and their significance for breeding and afforestation, Silvae Genet. 44 (1995) 298-303.

[107] Whitham T.G., Martinsen G.D., Floate K.D., Dungey H.S., Potts B.M., Keim P., Plant hybrid zones affect biodiversity: tools for a genetic-based understanding of community structure, Ecology 80 (1999) 416-428.

[108] Winfield M.O., Arnold G.M., Cooper F., Le Ray M., White J., Karp A., Edwards K.J., A study of genetic diversity in Populus nigra subsp. betulifolia in the Upper Severn area of the UK using AFLP markers, Mol. Ecol. 7 (1998) 3-10.

[109] Wolf D.E., Takebayashi N., Rieseberg L.H., Predicting the risk of extinction through hybridization, Conserv. Biol. 15 (2001) 10391053.

[110] Wood C.D., "A Most Dangerous Tree": the Lombardy Poplar in landscape gardening, Arnoldia 54 (1994) 24-30.

[111] Zsuffa L., The Genetics of Populus nigra L. Academia scientiarum et artium slavorum meridionalium (Zagreb), Annales Forestales 6/ 2 (1974) 29-53.

[112] Zsuffa L., Giordano E., Pryor L.D., Stettler R.F., Trends in poplar culture: some global and regional perspectives., in: Stettler R.F., Bradshaw H.D., Heilman P.E. Jr., Hinckley T.M. (Eds.), Biology of Populus, NRC Research Press, Ottawa, 1996, pp. 515-539. 